\title{
Start-Up Valuation for Internal Corporate Venture of PT Telekomunikasi Indonesia Tbk (Case Study: Venture B)
}

\author{
Cynthia Ghaida Subroto and Subiakto Sukarno
}

\begin{abstract}
To adapt with phenomenon in industry 4.0 which disruptive technology quickly emerges and can threaten many companies, PT Telekomunikasi Indonesia Tbk (Telkom) implements internal corporate venturing by establishing Amoeba Digital Program that is lab to manage innovation by employees who form a team named Amoeba. Amoebas are incubated by adopting lean start-up methodology thus they can be considered as a start-up. They have to go through steps of innovation journey and after all the steps are passed and there is potential upscale revenue, they will become Business As Usual of Telkom. Venture $B$ is one of Amoebas that has launched its product and generated revenues. However, recent Venture B's revenues is decreasing, thus Venture B needs to implement new business model and needs more financing. A problem confronting Telkom as the parent company which provides the venture capital is determining the value of the venture to determine whether funding should be provided. Therefore, this research is conducted to give insight on how much the venture is really worth and how Venture $B$ will be going in the future. Methodology used in this research is both qualitative and quantitative approach to understand the business situation and get a picture of the venture in a form of numbers or value. Combined of Damodaran and First Chicago method will be used to value the venture considering these methods can overcome issues emerged in valuing start-up company and provide better view on Venture B's overall potential through combining the value of three different scenarios. The value of Venture $B$ with new business model then will be compared with the value of Venture $B$ with existing business model. From the result, Telkom can know how much Venture B is really worth which can help Telkom determine future strategy.
\end{abstract}

Index Terms - corporate venturing, Damodaran method, First Chicago method, start-up, valuation

\section{INTRODUCTION}

Nowadays, the world including Indonesia is facing industry 4.0 which in this era, disruptive technology quickly emerges and can threaten many companies that are not agile in adapting to the growth of technology. Successful companies are companies that can fulfil people needs with digital innovation, even start-up companies can defeat mature corporations. These new start-ups could be a threat for PT Telekomunikasi Indonesia Tbk, or in short Telkom, a state-owned and the largest information and communication technology enterprise and telecommunications network in Indonesia. In few years, Telkom may be defeated by the

Cynthia Ghaida Subroto is with the Master of Business Administration, Bandung Institute of Technology, Ganesha St. 10, Bandung, 40132 Indonesia (e-mail: cynthia subroto@sbm-itb.ac.id).

Subiakto Sukarno is with the Master of Business Administration, Bandung Institute of Technology, Ganesha St. 10, Bandung, 40132 Indonesia (e-mail: subiakto@sbm-itb.ac.id). unicorn start-ups if the company does nothing.

To adapt with the phenomenon, Telkom is now transforming to become a digital telecommunication company as the vision of the company is "Be the King of Digital in the Region" with mission "Lead Indonesian Digital Innovation and Globalization". One way to achieve the goal is by implementing internal corporate venturing through establishment Amoeba Digital Program that is corporate innovation lab from Telkom to manage innovation by employees who form a team named Amoeba.

Amoebas are incubated by adopting lean start-up methodology thus they can be considered as startups. Each Amoeba has to go through innovation journey that consists of five steps which are Idea Generation and Validation, Customer Validation, Product Validation, Business Model Validation, and Market Validation. Amoebas will be fully funded by Telkom as the parent company as they passed each step. Amoebas that have passed all the steps, have reached zero EBITDA, and show potential upscale revenues will exit and become Business As Usual of Telkom.

Venture B is one of Amoeba that has launched its product, generated revenues, and reached Market Validation step. It gives services in selling digital game voucher and other digital voucher for merchants especially internet cafes that will sell online voucher to gamers. It should have been exit soon and become Business As Usual. However, recent Venture B's revenue is decreasing, thus Venture B needs to implement new business model, repeat the innovation journey from Customer Validation, and needs additional fund to develop the new business.

A problem confronting Telkom as the parent company which provides the venture capital is determining the value of the venture to determine whether funding should be provided. If the proposed product or service provided by the venture has no value or benefit to the company, then it should not be developed. Valuation can be a way to give insight on how much the venture is really worth and how Venture $\mathrm{B}$ will be going in the future.

Venture B was established in 2017. Since then, there are 8,095 registered merchants with 4,161 of them are active merchants that spread in various regions across all island in Indonesia. It also does not have any competitors that doing the same business. Currently Venture B is selling PC game vouchers from seven games that are PCgame1, PC game2, PCgame3, PCgame4, PCgame5, PCgame6, PCgame7. They also sell electricity (PLN) voucher and receive payment of PLN Postpaid, phone credit, and internet voucher.

In the new business model, Venture B will sell PC game voucher as existing in addition with mobile games voucher from three games and bundling of Wi-Fi and In Game Treatment voucher through merchants that are internet cafés 
or game centers. The In Game Treatment voucher is actually the cheapest mobile game voucher in every game that Venture B sold. Bundling voucher will be sold to be used for two hours.

The venture will no longer sell PLN, phone credit, and internet voucher to focus its portfolio as game voucher provider. In the implementation, Venture B will make partnership with Wi-Fi Corner (WiCo), product from Divisi Business Service (DBS) of Telkom to provide the Wi-Fi infrastructure and voucher.

\section{LITERATURE REVIEW}

\section{A. Corporate Venturing}

Corporate venturing or corporate entrepreneurship is the process by which individuals inside organizations pursue opportunities independent of the resources they currently control [9]. The process involves new venture creation within existing organizations and the transformation of organizations through strategic renewal. If the new venture is created within the parent company's organizational domain, it is called internal corporate venturing. The aim of corporate venturing is to improve company's competitive position and financial performance.

Funding the venture might be the most important aspect to analyze because in any organization, funds are limited thus financing requires good financial justification. The venture must demonstrate detailed financial projection to the parent company to convince them investing in the venture. The financial projection must show the potential for a return on the investment. Revenues and costs should be indicated through pro forma income statement.

To decide whether funding should be provided for the venture, its value should be determined by considering characteristics of the industry which the venture operates and growth of future markets. Nonfinancial factors should also be considered such as the uniqueness of the idea, its contribution to the company, the synergies of the idea with company's capability, length of time development, amount of investment involved, strength of the venture team, and possibility for more products or services.

\section{B. Start-Up}

The term start-up describes a company in the early stage of the business life cycle with a high degree of innovation looking for capital resources. Start-ups have to develop a scalable business model and a business plan. They depend on sufficient capital for realization of their business idea.

Reference [3] shows that the characteristics of start-up or young companies are no or have limited histories, small or no revenues result in operating losses, dependent on private equity rather than public markets, many of them do not survive and fail thus control system must be established to identify and solve emerged problem quickly, get multiple claims on equity by investors because of repeated equity raising, and more illiquid than investments in publicly traded firms.

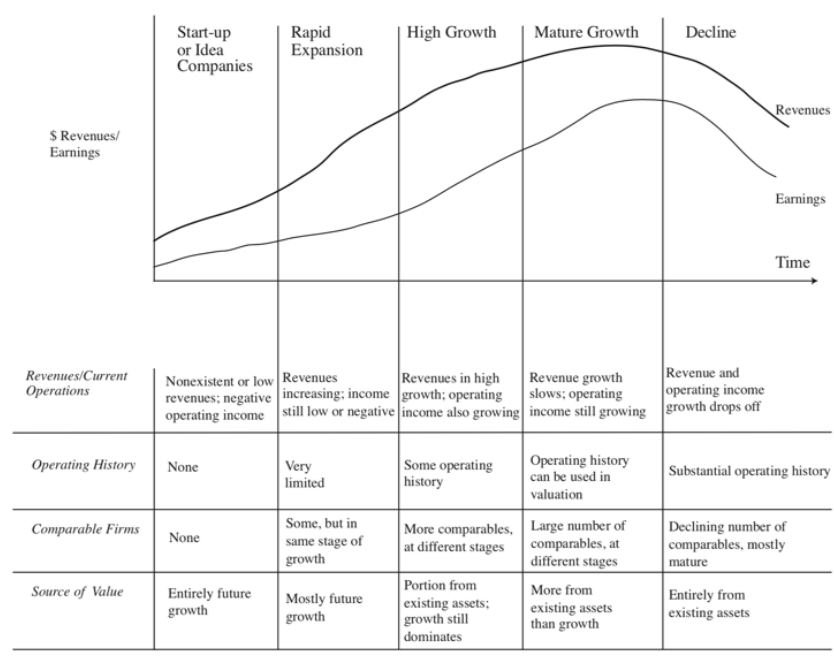

Fig. 1. Business Life Cycle Source: Damodaran, 2012

\section{Valuation}

Valuation is the process that links risk and return to determine the worth of an asset [7]. There are three key inputs to the valuation process which are cash flows (returns), timing, and risk which determines the required return. The value of a firm is the present value of expected cash flows generated by it, discounted back at a composite cost of capital that reflects both the sources and costs of financing used by it [3]. Valuation is based on intrinsic value of a company such as cash flow, assets, risks, and growth. Although it is a quantitative method, the inputs of valuation leave plenty of room for subjective judgements. However, there will still be uncertainty about the final numbers even at the end of the most careful and detailed valuation.

Valuation of start-up and established company is different because the characteristics of the company itself is different. Valuing business in the earlier stages in a life cycle is more challenging and difficult than valuing mature business since there is little information about the company.

\section{Start-Up Valuation Alternatives}

According to [20], there are two valuation methods for start-up that are traditional method and alternative method. Traditional methods consist of Discounted Cash Flow (DCF) method, market multiple method, and comparable transaction method. Alternative methods consist of Venture Capital (VC) method, First Chicago method, Damodaran method, Real Option method, Valuation of Intangibles, Cayenne Consulting Calculator, Dave Berkus Valuation model, Scorecard Valuation method, and Risk Factor Summation method.

The DCF, market multiple, and comparable transaction method cannot be used to value Venture B because it is more appropriate for established and publicly traded companies. Cayenne Consulting Calculator, Dave Berkus Valuation model, Scorecard Valuation model, and Risk Factor Summation method are also not appropriate to be used because it is more suitable for pre-revenue start-ups, whereas $\mathrm{VC}$ method is less objective because usually result in higher than normal discount rate. Real option method has to be used selectively only in case where the expected 
expansion opportunity cannot be reflected within the cash flow growth.

After analyzing all the methods, it can be concluded that Damodaran and First Chicago method would be the most appropriate method to value Venture B. Damodaran method is DCF method with some adjustments to overcome the problems emerged in valuing a start-up company. The First Chicago method will complement since it combines the value of three different scenarios which are success, sideway, and failure. Therefore, it provides a better view on the Venture B's overall potential.

\section{E. Discounted Cash Flow Valuation}

Discounted Cash Flow (DCF) valuation is the foundation on which all other valuation approaches are built [4]. It has its foundation in the present value rule, where the value of any asset is the present value of expected future cash flow on it. The cash flow that computed in calculation is usually the free cash flow. To estimate the future free cash flow, income statement, balance sheet, and statement of cash flow need to be forecasted or it is called pro forma financial statements.

Free Cash Flow = Operating Cash Flow Capital Expenditures

Then, the formula to calculate present value of expected future cash flow is as follows.

Where

$$
\text { Value }=\sum_{t=1}^{t=n} \frac{F C F_{t}}{(1+r)^{t}}
$$

$$
\begin{aligned}
\mathrm{n} & =\text { Life of the asset } \\
\mathrm{FCF}_{\mathrm{t}} & =\text { Expected free cash flow in period } \mathrm{t} \\
\mathrm{r} & =\text { discount rate }
\end{aligned}
$$

The discount rate computed in the calculation is obtained from Weighted Average Cost of Capital (WACC). To calculate WACC, it needs data equity and debt of the company.

$$
W A C C=\frac{k_{e}\left(\frac{E}{D+E}\right)}{k_{d}\left(\frac{D}{D+E}\right)}
$$

Where

$$
\begin{aligned}
\mathrm{ke}_{\mathrm{e}} & =\text { Cost of Equity } \\
\mathrm{k}_{\mathrm{d}} & =\text { Current borrowing rate }(1-\mathrm{t}) \\
\mathrm{E} & =\text { Value of Equity } \\
\mathrm{D} & =\text { Value of Debt }
\end{aligned}
$$

The inputs of debt in the calculation must include both short-term and long-term debt. To calculate the cost of equity, Capital Asset Pricing Model (CAPM) approach will be used because it considers different set of factors than dividends alone and can apply to any kind of investment.

Where

$$
k_{e}=r_{f}+\beta x\left(r_{m}-r_{f}\right)
$$

$$
\begin{aligned}
\mathrm{r}_{\mathrm{f}} & =\text { risk free rate } \\
\beta & =\text { Beta } \\
\mathrm{r}_{\mathrm{m}} & =\text { expected return on the market } \\
\mathrm{r}_{\mathrm{m}}-\mathrm{r}_{\mathrm{f}} & =\text { market risk premium }
\end{aligned}
$$

The formula explained above only calculate present value of future cash flow or value of a company in some certain period. However, the remaining value of the company after discounted period should be taken into account. This value is called terminal value. The formula to calculate terminal value can be seen below.

Where

$$
\text { Terminal Value }=\frac{F C F_{n}(1+g)}{(r-g)}
$$

$$
\begin{aligned}
\mathrm{FCF}_{\mathrm{n}} & =\text { Free Cash Flow in year } \mathrm{n} \\
\mathrm{g} & =\text { perpetuity growth rate } \\
\mathrm{r} & =\text { discount rate }
\end{aligned}
$$

In this calculation, it is assumed that the growth after discounted period will be constant. Finally, the enterprise value is obtained by summing up the present value in discounted period with the discounted terminal value.

\section{F. Damodaran Method}

To apply DCF models to value young companies, Damodaran has found a way to deal with the characteristics of young company by estimating the data needed to be computed systematically.

\section{1) Estimating Future Cash Flows}

There are two approaches to estimate the process which are top down approach and bottom up approach. First thing to do in top down approach are estimating the potential market, market size, and market share that will be captured. After that, estimate operating expenses, investment for growth, tax effect, and the last, check for internal consistency. In bottom up approach, the first thing to do is estimating investment to run the business. After that, estimate units of sales or revenues, operating cost, taxable income, and the resulting taxes. The last step is estimating additional reinvestment to scale up the business.

\section{2) Estimating Discount Rates}

Beta cannot be estimated using the standard practice from stock prices since young companies are usually not publicly traded. Cost of equity has to incorporate to some or maybe all of the firm specific risk. Young companies almost never have bonds outstanding. Consequently, there will be no bond rating to measure default risk. There no market values that can be used to weight debt and equity to calculate cost of capital since equity and debt in young companies is not traded.

\section{3) Estimating Value today and adjusting for survival}

Estimation of cash flow and discount rates are key building blocks towards valuing a business. However, there are other issues to deal with to get the value of company. The first is determining what will happen at the end of forecast period and the second is adjusting for likelihood that the business may not survive.

\section{a) Terminal Value}

There are three ways to estimate the terminal value for young companies. The first one is to value the company as going concern and make assumptions that cash flows will be growing in perpetuity. The second is to make assumption about how long cash flow is expected to continue in certain period and estimate the present value of these cash flows. Lastly, assume the company will be liquidated at the end of forecast period and the salvage value of any assets accumulated over the company's life is the terminal value.

\section{b) Survival}

There is two-step approach to consider this issue. The 
first step is valuing the company on the assumption that it will survive and makes it to financial health. The second step is to bring the likelihood that the firm will not survive. The probability of failure can be assessed in one of three ways. The first one is by using sector averages data made by Knaup and Piazza. The second is by using probits approach and the last is by doing simulations under condition if the company will face failure and specify the probability.

\section{G. First Chicago Method}

The First Chicago Method was first introduced by Sahlman and Scherlis (1987). It is developed and named after the late First Chicago Bank. It is a valuation approach used by investors for early stage companies that has dynamic growth. The method answers to questions what if the company has a chance of becoming huge or worst, face a failure, by making valuations based on three case scenarios which are worst-case scenario, normal-case scenario, and best-case scenario. Each scenario is made with the DCF method. The step to do valuation using this method is first define different future scenarios for the company. Then, estimate divestment price for each scenario. After that, determine required return and calculate valuation for each scenario. Last, estimate probabilities of scenarios and calculate weighted sum.

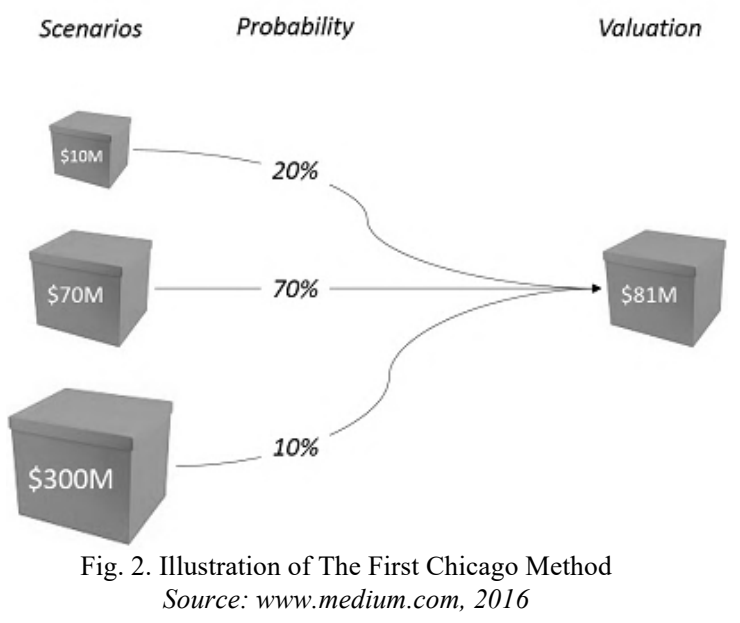

\section{Methodology}

The methodology used in this research is both qualitative and quantitative approach. Qualitative approach is done by analyzing external and internal environment of the venture to understand the business situation and analyze the prospect of the business. External environment will be analyzed using PESTLE model and Porter's Five Forces whereas internal environment will be analyzed based on the venture's resources and capabilities using VRIO framework. Then, SWOT analysis can summarize the internal and external environment to identify strengths, weaknesses, opportunities, and threats of the venture.

Quantitative approach is done by calculating the value of the venture based on projected cash flow calculation to get a picture of the venture in a form of value or numbers. Combined of Damodaran and First Chicago method will be used to value the venture based on analyzing literature review. Valuation will be conducted under two different condition which the first condition is if Telkom give additional fund, and the second condition is if Telkom does not give additional fund and the venture will operate as existing. Both values then are compared, and the results can help Telkom determine future strategy.

All data available to be analyzed are collected from primary data and secondary resources. Primary data is collected through interview to define business issues, get big picture about the company and business situation, and also to know the company's strategy. The interviewees are the CEO and CMO of Venture B. Secondary data is collected through venture's internal data and available public data resources. The secondary data consists of venture documents such as venture report, venture's plan, and venture's data. There are also a lot of supporting data obtained from online media such as market data and customer behavior that related with the business of the venture. Books and academic papers from online and offline media are also used to support the valuation process.

\section{ANALYSIS AND RESULTS}

\section{A. Analysis of Business Situation}

\section{1) External Environment}

\section{a) General Environment}

- Political: Indonesia Government supports game industry to grow, proven by establishment of Badan Ekonomi Kreatif (Bekraf) that manage and develop creative industry including game. The Ministry of Communication and Information Technology (Kominfo) also has built digital infrastructure with the Palapa Ring. However, Kominfo appealed to the regional government to issue regulations that limit the operating hours of internet cafes not up to 24 hours and recent issue arose that there will be restrictions of particular game regarding the user's age and duration of playing game.

- Economic: Game industry is growing fast and has lucrative economic potential. Global market of game industry reached USD 134.9 billion in 2018, more than half of them came from mobile game segment. This phenomenon affects Indonesia which reached total expenditure of USD 1,130 million in 2018 and made Indonesia the $17^{\text {th }}$ largest game market in the world based on revenue and biggest market for mobile games in South East Asia (SEA).

- Social: In Indonesia, more than half of the online population play mobile games. In 2017, the number of Indonesian gamers reached 55 million. Indonesia is the second largest downloader of mobile games behind China. Most people love to play strategy, puzzle, adventure, and action games. People nowadays need Wi-Fi access as their primary needs and places with free Wi-Fi are attracted many people. In line with this, mobile gamers also have the highest growth among all game segments which proved that nowadays people tend to play with they own devices.

- Technological: Game industry is very related with development of technology. People can play games using their immobile or mobile gadget, with single or multiplayer, offline or online. With the rise of internet, smartphones, and online games, people can play mobile games anytime anywhere. The emergence of decentralized gaming platforms allows gamers to monetize their skills.

- Legal: Venture B must obey Telkom's regulation to run 
its business and must be aligned with business of Telkom. Things that Venture B has to pay attention are intellectual property rights and contracts made with all stakeholders.

- Environmental: Although digital games are materialfree, it requires a lot of energy. Producing a digital game creates $53 \%$ more $\mathrm{CO}_{2}$ than a physical game whereas download and gameplay also produced $\mathrm{CO}_{2}$. In addition, gaming $\mathrm{PC}$ can use up to 5 monitors and that energy is equivalent of 3 refrigerators.

\section{b) Industry Environment}

Game industry can be divided into console game industry, PC game industry, and mobile game industry. Console game industry will not be analyzed further since Venture B is not related with this industry.

\section{- Threat of New Entrants}

PC game has moderate threat of new entrants because it needs high investment to develop PC games and online games. However, mobile game industry has high threat of new entrants because a lot of local players participate in the industry as well as global players. It is also easier and cheaper to develop the game rather than another segment.

\section{- Bargaining Power of Suppliers}

Suppliers in PC game industry are moderately powerful because there are a lot of software suppliers which are not differentiated greatly and dependent on buyers for its revenues whereas the hardware suppliers have more control on the prices they charge. In mobile game industry, bargaining power of suppliers is low because there are plentiful of developer companies which provide a wide range of products.

\section{- Bargaining Power of Buyers}

Bargaining power of buyers in both PC game and mobile game industry is high because they could switch to another product easily.

\section{- Threat of Substitute Products}

In PC game industry, the threat of substitute is moderate because the fast-paced lifestyle of consumers may lead them to find entertainment products that are more portable, and the biggest threat comes from its "friend" which is mobile game. However, PC game segment has already had its own market that attached to some game developers.

The threat of substitute in mobile game industry is also moderate because there are a lot of products that compete for a mobile user's time especially for casual games. In spite of that, gamers who play multi-player online games usually have attached with some mobile game developers.

\section{- Intensity of Rivalry Among Competitors}

The intensity of rivalry is high in each type of games both in PC game and mobile game industry. Companies that develop strategy games will compete intensely, but they do not really compete with companies that develop puzzle games. There are large number of companies who create homogeneous products in the industry, resulting in low switching cost.

\section{2) Internal Environment}

a)

\section{(1) Tangible resources}

- Financial: Telkom is the biggest telecommunication in Indonesia which can invest huge amount of money to
Venture B.

- Organizational: Venture B has its own formal reporting structure and routines meeting, also they have to make a report to Telkom regularly.

- Physical: Venture B's office is located at Telkom and allowed to use all Telkom facilities and infrastructure if needed.

\section{(2) Intangible resources}

- Human: Currently Venture B consists of a team of ten, with solid three people hold C-level job and the rest are outsourced. The chiefs have skill and knowledge that could support the sales, proven by Venture B's achievement in 2017 becoming the best product of Telkom that can generate the most sales.

- Innovation: Venture B has capacity to innovate, proven by the chief's achievement becoming the best innovator in 2017. The team is also facilitated to share knowledge from top management of Telkom and from practitioners of startup company that have cooperated with Telkom.

- Reputational: Venture B has good reputation related with its customers and partnerships as it can maintain relationship with them. Venture B is also under name of Telkom which already have strong brand name in Indonesia.

\section{b) Capabilities}

Resources that are integrated to achieve some mission will yield to capabilities. The capabilities of Venture B are solid and integrity $\mathrm{C}$-level employees, ability to envision the future game industry and internet cafes, ability to innovate and share knowledge with experts directly, ability to use facilities and infrastructure of biggest telecommunication company in Indonesia, effective marketing to promote Venture B's product, strong relationship with customers and partnerships, innovative product which make Venture B a pioneer, and effective organizational management process.

\section{c) VRIO Framework}

Resource and capability must have four attributes that are valuable, rare, imperfectly imitable, and able to be exploited by the company's organizational process in order to become the core competencies of the company. These attributes then are developed into VRIO (Value, Rarity, Imitability, and Organization) framework.

TABLE I: THE VRIO FRAMEWORK OF VENTURE B

\begin{tabular}{lcccccc}
\multicolumn{1}{c}{ TABLE I: THE VRIO FRAMEWORK OF VENTURE B } \\
\hline \hline \multicolumn{1}{c}{ Resource/Capability } & $\mathrm{V}$ & $\mathrm{R}$ & $\mathrm{I}$ & $\mathrm{O}$ & $\begin{array}{l}\text { Competitive } \\
\text { Implications }\end{array}$ & $\begin{array}{c}\text { Economic } \\
\text { Performance }\end{array}$ \\
\hline $\begin{array}{l}\text { Solid and integrity C- } \\
\text { level employees }\end{array}$ & Yes & Yes & Yes & Yes & $\begin{array}{l}\text { Sustained } \\
\text { competitive } \\
\text { advantage }\end{array}$ & $\begin{array}{l}\text { Above } \\
\text { normal }\end{array}$ \\
\hline $\begin{array}{l}\text { Ability to envision the } \\
\text { future game industry and } \\
\text { internet cafes }\end{array}$ & Yes & No & No & Yes & $\begin{array}{l}\text { Competitive } \\
\text { Parity }\end{array}$ & Normal \\
\hline $\begin{array}{l}\text { Ability to innovate and } \\
\text { share knowledge with } \\
\text { experts directly }\end{array}$ & Yes & Yes & Yes & Yes & $\begin{array}{l}\text { Sustained } \\
\text { competitive } \\
\text { advantage }\end{array}$ & $\begin{array}{l}\text { Above } \\
\text { normal }\end{array}$ \\
\hline $\begin{array}{l}\text { Ability to use facilities } \\
\text { and infrastructure of } \\
\text { biggest } \\
\text { telecommunication } \\
\text { company in Indonesia }\end{array}$ & Yes & Yes & Yes & Yes & $\begin{array}{l}\text { Sustained } \\
\text { competitive } \\
\text { advantage }\end{array}$ & $\begin{array}{l}\text { Above } \\
\text { normal }\end{array}$ \\
\hline $\begin{array}{l}\text { Effective marketing to } \\
\text { promote Venture B's } \\
\text { product }\end{array}$ & Yes & No & No & Yes & $\begin{array}{l}\text { Competitive } \\
\text { Parity }\end{array}$ & Normal \\
\hline $\begin{array}{l}\text { Strong relationship with } \\
\text { customers and } \\
\text { partnerships }\end{array}$ & Yes & Yes & Yes & Yes & $\begin{array}{l}\text { Sustained } \\
\text { competitive } \\
\text { advantage }\end{array}$ & $\begin{array}{l}\text { Above } \\
\text { normal }\end{array}$ \\
\hline $\begin{array}{l}\text { Innovative product } \\
\text { which make Venture B a } \\
\text { pioneer }\end{array}$ & Yes & Yes & No & Yes & $\begin{array}{l}\text { Temporary } \\
\text { competitive } \\
\text { advantage }\end{array}$ & $\begin{array}{l}\text { Above } \\
\text { normal }\end{array}$ \\
\hline $\begin{array}{l}\text { Effective organizational } \\
\text { management process }\end{array}$ & Yes & No & No & Yes & $\begin{array}{l}\text { Competitive } \\
\text { Parity }\end{array}$ & Normal \\
\hline \hline
\end{tabular}


3) SWOT Analysis

SWOT analysis of Venture B can be seen in table below.

TABLE II: SWOT ANALYSIS OF VENTURE B

\begin{tabular}{|c|c|}
\hline Strengths & Weakness \\
\hline $\begin{array}{l}\text { 1. A pioneer of B2B voucher games seller to } \\
\text { merchant especially internet cafes. } \\
\text { 2. Solid and integrity C-level employees. } \\
\text { 3. Ability to innovate and share knowledge } \\
\text { with experts directly. } \\
\text { 4. Ability to use facilities and infrastructure } \\
\text { of biggest telecommunication in } \\
\text { Indonesia. } \\
\text { 5. Strong relationship with customers and } \\
\text { partnerships. }\end{array}$ & $\begin{array}{l}\text { 1. Venture B is not really independent } \\
\text { to develop its business because it is } \\
\text { under the auspices of Telkom and its } \\
\text { regulation. } \\
\text { 2. Employees beside C-level holders } \\
\text { are outsourced, make them less } \\
\text { engage with the venture. }\end{array}$ \\
\hline Opportunities & Threats \\
\hline $\begin{array}{l}\text { 1. Development of digital infrastructure. } \\
\text { 2. Game industry is supported by Indonesia } \\
\text { government to grow through BEKRAF. } \\
\text { 3. Mobile game segment has highest } \\
\text { growth among other game segments. } \\
\text { 4. Indonesia is the biggest market for } \\
\text { mobile games in SEA. } \\
\text { 5. Phenomena "Wi-Fi everywhere" and } \\
\text { "Bring Your Own Devices". } \\
\text { 6. Emergence of decentralized gaming } \\
\text { platforms. }\end{array}$ & 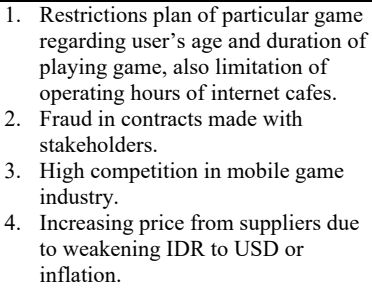 \\
\hline
\end{tabular}

\section{B. Valuation of Venture B (First Condition)}

To estimate the future cash flow of Venture B, bottom up approach is used because it is more suitable for business that face restrictions on raising additional capital. Venture B cannot obtain capital easily since there is only Telkom who funds the capital. Bottom up approach of cash flow will yield lower expected cash flow and earnings because it works with capacity constraints, however it will prevent over estimated cash flow result from top down approach.

\section{1) Estimating Cash Flow}

\section{a) Capacity Investment}

Venture B does not need new set-up cost regarding land, building, plant, equipment, and intangibles. It also does not have inventory and receivables because the supplier is making the transaction through Telkom. Therefore, working capital required is determined based on operating cost which is IDR $1,259,820,000$ in the first year.

b) Unit Sales/Revenues and Cost of Sales (COS)

The revenues and COS projection of each voucher sold is determined using different approaches. PC game vouchers revenues are projected using trend from historical data revenues to get the projection as close as Venture B capacity. The trend is also in line with the PC games trend which is decreasing. Projected COS of PC game vouchers are determined by percentage of sales according to historical data which is different for every game and assumed will be constant for the next five years.

Mobile game voucher revenues are projected based on expected market share acquired, based on Venture B's historical capability of acquiring market share of PC game vouchers. By selling PC game vouchers from seven games, Venture B could acquire $0.017 \%$ market share in 2017 and $0.009 \%$ in 2018. Therefore, for mobile game vouchers revenues, the market share is expected to be $0.005 \%$ in 2019 and will reach $0.10 \%$ in 2023 . Projected COS of mobile game vouchers are determined by percentage of sales according to Venture B expected which is different for every game and assumed will be constant for the next five years.

Bundling vouchers sales are projected based on expected cities and merchants acquired. The acquisition plan is made based on historical capabilities of Venture B and the venture's plan.

TABLE III: PROJECTED CITIES ACQUISITION

\begin{tabular}{lcccccc}
\hline \hline \multirow{2}{*}{ Island } & 2019 & 2020 & 2021 & 2022 & 2023 & \\
\cline { 2 - 6 } & $\begin{array}{c}\text { Cities } \\
\text { Acquired }\end{array}$ & $\begin{array}{c}\text { Cities } \\
\text { Acquired }\end{array}$ & $\begin{array}{c}\text { Cities } \\
\text { Acquired }\end{array}$ & $\begin{array}{c}\text { Cities } \\
\text { Acquired }\end{array}$ & $\begin{array}{c}\text { Cities } \\
\text { Acquired }\end{array}$ & Total \\
\hline Jawa & 7 & 15 & 12 & - & - & 34 \\
Bali \& Nusa & - & 3 & - & - & - & 3 \\
Sumatra & - & 14 & 17 & - & - & 31 \\
Kalimantan & - & - & 9 & - & - & 9 \\
Sulawesi & - & - & 11 & - & - & 11 \\
Maluku-Papua & - & - & 5 & - & - & 5 \\
\hline Total & 7 & 32 & 54 & - & - & 93 \\
\hline Accumulative & 7 & 39 & 93 & 93 & 93 & \\
\hline \hline
\end{tabular}

TABLE IV: PROJECTED MERCHANTS ACQUISITION - NORMAL-CASE

\begin{tabular}{lcccccc}
\hline \hline \multirow{2}{*}{ Island } & 2019 & 2020 & 2021 & 2022 & 2023 & \multirow{2}{*}{ Total } \\
\cline { 2 - 5 } & $\begin{array}{c}\text { Merchants } \\
\text { Acquired }\end{array}$ & $\begin{array}{c}\text { Merchants } \\
\text { Acquired }\end{array}$ & $\begin{array}{c}\text { Merchants } \\
\text { Acquired }\end{array}$ & $\begin{array}{c}\text { Merchants } \\
\text { Acquired }\end{array}$ & $\begin{array}{c}\text { Merchants } \\
\text { Acquired }\end{array}$ & \\
\hline Jawa & 135 & 310 & 1,145 & 1,435 & 275 & 3,300 \\
Bali \& Nusa & - & 7 & 26 & 42 & 8 & 83 \\
Sumatra & - & 68 & 167 & 270 & 52 & 557 \\
Kalimantan & - & - & 57 & 103 & 18 & 178 \\
Sulawesi & - & - & 56 & 121 & 20 & 197 \\
Maluku-Papua & - & - & 9 & 19 & 7 & 35 \\
\hline Total & 135 & 385 & 1,460 & 1,990 & 380 & 4,350 \\
\hline Accumulative & 135 & 520 & 1,980 & 3,970 & 4,350 & \\
\hline \hline
\end{tabular}

Based on historical data, Venture B can acquire 4,161 merchants in 93 cities in two years. Therefore, it will be possible that Venture B can acquire 4,350 merchants in 93 cities in five years. The number of merchants' distribution in each city is based on historical data with assumption that in every city there will be additional number of merchants.

To determine the number of sales, Venture B has decided the target number of users for every merchant. Several assumptions are made such as business hours of merchants are assumed 12 hours per day with expected number of users per two hours will be 3 people in weekdays and 8 people in weekend. Number of operating weeks per year is assumed to be 49 weeks, whereas usually there are 52 weeks in a year. Three weeks are assumed to be holidays thus merchants will not be operating. From the assumptions, target number of users is estimated will be 9,114 people per year or around 760 per month.

The price of the bundling vouchers is determined based on its COS. COS of Wi-Fi had already determined by DBS whereas COS of In Game Treatment will be determined by multiplying percentage of active users of the three games in Indonesia (estimate buyers) with COS from suppliers. It is assumed that the cost will increase according to inflation rate, which expected will be constant at $3.38 \%$ for the next five years. This rate comes from average of inflation rate for the past 30 months.

The price is then decided for the next five years. The price in the first and second year is IDR 5,000 to attract more customers since the product is still new in the market. The price will be increasing in year three by IDR 200 to align the increased cost of sales and in year four the price will stay the same to attract more customers and merchants. Then, in year five the price will increase by IDR 300 because it is assumed that the product is already well-known and has acquired the targeted market.

TABLE V: TOTAL EXPECTED REVENUES - NORMAL-CASE (IN IDR)

\begin{tabular}{lccccc}
\hline \hline \multicolumn{1}{c}{ Description } & 2019 & 2020 & 2021 & 2022 & 2023 \\
\hline $\begin{array}{l}\text { Bundling } \\
\text { Voucher }\end{array}$ & $2,622,000,000$ & $15,665,500,000$ & $62,164,960,000$ & $145,018,640,000$ & $209,459,800,000$ \\
\hline \begin{tabular}{l} 
PC Game \\
\hline Voucher
\end{tabular} & & & & & \\
\hline PCgame1 & $73,202,485$ & $67,065,035$ & $63,045,771$ & $60,045,750$ & $57,649,784$
\end{tabular}




\begin{tabular}{|c|c|c|c|c|c|}
\hline PCgame2 & $98,235,454$ & $86,426,208$ & $78,558,972$ & $72,797,459$ & $68,324,831$ \\
\hline PCgame3 & $31,345,524$ & $28,532,040$ & $26,432,025$ & $24,754,849$ & $23,358,108$ \\
\hline PCgame4 & $7,761,988$ & $7,738,142$ & $7,699,491$ & $7,644,529$ & $7,572,021$ \\
\hline PCgame5 & $6,788,072$ & $6,505,594$ & $6,314,984$ & $6,170,697$ & $6,054,503$ \\
\hline PCgame6 & $15,813,007$ & $15,009,154$ & $14,409,150$ & $13,929,957$ & $13,530,888$ \\
\hline $\begin{array}{l}\text { PCgame7 } \\
\text { Pal }\end{array}$ & 939,753 & $\begin{array}{r}886,701 \\
\end{array}$ & 850,902 & 823,804 & $\begin{array}{r}801,982 \\
\end{array}$ \\
\hline $\begin{array}{l}\text { PC Game } \\
\text { Voucher }\end{array}$ & $234,086,283$ & $212,162,874$ & $197,311,297$ & $186,167,045$ & $177,292,115$ \\
\hline \multirow{2}{*}{\multicolumn{6}{|c|}{$\begin{array}{l}\text { Mobile Game } \\
\text { Voucher }\end{array}$}} \\
\hline & & & & & \\
\hline $\begin{array}{l}\text { Mgame1 } \\
\text { Mgame2 }\end{array}$ & $\begin{array}{r}299,0404,000 \\
29,904,000\end{array}$ & $\begin{array}{r}1,005,50,209 \\
185,450,327\end{array}$ & $359,782,500$ & $\begin{array}{r}, 49,01,481,846 \\
549,58\end{array}$ & 750475385 \\
\hline Mgame3 & $59,808,000$ & $370,900,654$ & $719,565,000$ & $\begin{array}{r}r 4,580,1,4040 \\
1,099,163,692\end{array}$ & $\begin{array}{r}1500,4 / 50,769 \\
1,500,950\end{array}$ \\
\hline $\begin{array}{l}\text { Mobile } \\
\text { Game } \\
\text { Voucher }\end{array}$ & $388,752,000$ & $2,410,854,250$ & $4,677,172,500$ & $7,144,564,000$ & $9,756,180,000$ \\
\hline $\begin{array}{l}\text { Total } \\
\text { Revenues }\end{array}$ & $3,244,838,283$ & $18,288,517,124$ & $67,039,443,797$ & $152,349,371,045$ & $219,393,272,115$ \\
\hline
\end{tabular}

TABLE VI: TOTAL COST OF SALES- NORMAL-CASE (IN IDR)

\begin{tabular}{|c|c|c|c|c|c|}
\hline $\begin{array}{l}\text { Description } \\
\end{array}$ & 2019 & 2020 & 2021 & 2022 & 2023 \\
\hline \multicolumn{6}{|l|}{ Bundling } \\
\hline$\frac{\overline{V o u c h e r}}{\text { Wi-Fi }}$ & $1,284,780,000$ & $7,935,495,837$ & $31,302,271,476$ & $75,489,708,826$ & $106,570,987,038$ \\
\hline $\begin{array}{c}\text { In Game } \\
\text { Treatment }\end{array}$ & $1,012,495,385$ & $6,253,718,854$ & $24,668,352,090$ & $59,491,104,915$ & $83,985,299,047$ \\
\hline $\begin{array}{l}\text { Bundling } \\
\text { Voucher }\end{array}$ & $2,297,275,385$ & $14,189,214,691$ & $55,970,623,566$ & $134,980,813,741$ & $190,556,286,084$ \\
\hline \multirow{2}{*}{\multicolumn{6}{|c|}{$\begin{array}{l}\text { PC Game } \\
\text { Voucher }\end{array}$}} \\
\hline & & & & & \\
\hline PCgame1 & $70,133,548$ & $64,253,404$ & $60,402,643$ & $57,528,395$ & $55,232,877$ \\
\hline PCgame2 & $80,374,463$ & $70,712,352$ & $64,275,523$ & $59,561,558$ & $55,902,134$ \\
\hline PCgame3 & $26,697,596$ & $24,301,296$ & $22,512,672$ & $21,084,188$ & $19,894,557$ \\
\hline PCgame4 & $7,133,636$ & $7,111,721$ & $7,076,199$ & 7,025,686 & $\begin{array}{l}6,959,048 \\
\end{array}$ \\
\hline PCgame5 & $5,581,303$ & $5,349,044$ & $\begin{array}{l},, 070,199 \\
5,192,321\end{array}$ & $\begin{array}{l}5,073,684 \\
5\end{array}$ & $\begin{array}{l}4,978,147 \\
4,95,0\end{array}$ \\
\hline PCgame6 & $13,314,830$ & $12,637,972$ & $12,132,758$ & $11,729,268$ & $11,393,245$ \\
\hline PCgame7 & $\begin{array}{r}892,765 \\
\end{array}$ & $\begin{array}{r}842,366 \\
\end{array}$ & $\begin{array}{r}808,357 \\
\end{array}$ & 782,614 & 761,882 \\
\hline $\begin{array}{l}\text { PC Game } \\
\text { Voucher }\end{array}$ & $204,128,140$ & $185,208,154$ & $172,400,473$ & $162,785,394$ & $155,121,890$ \\
\hline \multicolumn{6}{|l|}{ Mobile Game } \\
\hline$\frac{\text { Voucher }}{\text { Mgame1 }}$ & $215,305,870$ & $1,335,224,182$ & $2,590,398,745$ & $3,956,935,439$ & $5,403,349,230$ \\
\hline Mgame2 & $26,166,000$ & $162,269,036$ & $314,809,688$ & $480,884,115$ & $656,665,962$ \\
\hline Mgame3 & $52,332,000$ & $324,538,072$ & $629,619,375$ & $961,768,231$ & $1,313,331,923$ \\
\hline $\begin{array}{l}\text { Mobile } \\
\text { Game } \\
\text { Voucher }\end{array}$ & $293,803,870$ & $1,822,031,290$ & $3,534,827,807$ & $5,399,587,785$ & $7,373,347,115$ \\
\hline $\begin{array}{l}\text { Total Cost of } \\
\text { Sales }\end{array}$ & $2,795,207,395$ & $16,196,454,135$ & $59,677,851,846$ & $140,543,186,920$ & $198,084,755,089$ \\
\hline
\end{tabular}

\section{c) Operating Cost}

The operating cost is categorized into four categories which are People, Marketing, Operation, and General Affairs.

TABLE VII: TOTAL OPERATING COST - NORMAL-CASE (IN IDR)

\begin{tabular}{|c|c|c|c|c|c|}
\hline $\begin{array}{l}\text { Operating Cost } \\
\end{array}$ & 2019 & 2020 & 2021 & 2022 & 2023 \\
\hline \multicolumn{6}{|l|}{ People } \\
\hline $\begin{array}{l}\text { Internal } \\
\text { Partnership }\end{array}$ & $44,400,000$ & $48,000,000$ & $105,600,000$ & $169,200,000$ & $240,000,000$ \\
\hline $\begin{array}{l}\text { Designer } \\
\text { Web Developer }\end{array}$ & $\begin{array}{l}32,000,000 \\
31,200000\end{array}$ & $\begin{array}{l}42,000,000 \\
68,400000\end{array}$ & $\begin{array}{r}91,200,000 \\
148,800,000\end{array}$ & $\begin{array}{l}151,200,000 \\
234000,000\end{array}$ & $\begin{array}{l}216,000,000 \\
326000,000\end{array}$ \\
\hline $\begin{array}{l}\text { Mobile } \\
\text { Developer }\end{array}$ & $37,200,000$ & $81,600,000$ & $180,000,000$ & $279,000,000$ & $384,000,000$ \\
\hline $\begin{array}{l}\text { Backend } \\
\text { Engineer }\end{array}$ & $43,200,000$ & $94,800,000$ & $204,000,000$ & $315,000,000$ & $432,000,000$ \\
\hline $\begin{array}{l}\text { Frontend } \\
\text { Engineer }\end{array}$ & $31,200,000$ & $68,400,000$ & $148,800,000$ & $234,000,000$ & $326,400,000$ \\
\hline $\begin{array}{r}\text { External } \\
\text { Partnership }\end{array}$ & $50,400,000$ & $55,200,000$ & $120,000,000$ & $189,000,000$ & $264,000,000$ \\
\hline Telemarketing & 600,000 & $1,320,000$ & $2,190,000$ & $2,400,000$ & $2,640,000$ \\
\hline $\begin{array}{l}\text { Branch } \\
\text { Mangaer }\end{array}$ & $145,000,000$ & $940,240,000$ & $2,909,880,000$ & $4,363,560,000$ & $4,776,480,000$ \\
\hline Esport Analyst & $48,000,000$ & $184,800,000$ & $364,800,000$ & $436,800,000$ & $462,000,000$ \\
\hline Total People & $463,200,000$ & $1,584,760,000$ & $4,275,270,000$ & $6,374,160,000$ & $7,429,920,000$ \\
\hline \multicolumn{6}{|l|}{ Marketing } \\
\hline $\begin{array}{r}\text { Marketing } \\
\text { Management }\end{array}$ & $64,000,000$ & $101,400,000$ & $140,400,000$ & $166,050,000$ & $193,500,000$ \\
\hline $\begin{array}{l}\text { Mini Game } \\
\text { Competition }\end{array}$ & $27,200,000$ & $42,660,000$ & $73,440,000$ & $78,360,000$ & $83,280,000$ \\
\hline $\begin{array}{l}\text { GOOB for } \\
\text { Validation }\end{array}$ & $153,600,000$ & $232,620,000$ & $451,140,000$ & $301,380,000$ & $274,920,000$ \\
\hline Event Booth & $159,100,000$ & $470,810,000$ & $2,541,896,000$ & $1,654,930,000$ & $1,375,064,000$ \\
\hline $\begin{array}{c}\text { Brand } \\
\text { Awareness }\end{array}$ & $147,500,000$ & $483,840,000$ & $1,006,560,000$ & $1,038,240,000$ & $538,560,000$ \\
\hline $\begin{array}{l}\text { Gathering } \\
\text { Warnet }\end{array}$ & $131,200,000$ & $408,000,000$ & $1,282,752,000$ & $1,285,464,000$ & $1,164,480,000$ \\
\hline $\begin{array}{l}\text { Indihome } \\
\text { Gamer }\end{array}$ & $7,000,000$ & $10,920,000$ & $33,000,000$ & $39,900,000$ & $25,200,000$ \\
\hline PoinBOS & $12,000,000$ & $12,360,000$ & $38,160,000$ & $52,320,000$ & $26,880,000$ \\
\hline $\begin{array}{l}\text { Voucher } \\
\text { Gimmick }\end{array}$ & $25,000,000$ & $62,880,000$ & $132,000,000$ & $206,640,000$ & $90,000,000$ \\
\hline $\begin{array}{l}\text { Member get } \\
\text { member }\end{array}$ & $5,000,000$ & $12,480,000$ & $26,400,000$ & $41,040,000$ & $14,400,000$ \\
\hline Total Marketing & $731,600,000$ & $1,837,970,000$ & $5,725,748,000$ & $4,864,324,000$ & $3,789,884,000$ \\
\hline $\begin{array}{l}\text { Operation } \\
\text { Appear.in pro } \\
\text { Hosting }\end{array}$ & $1,500,000$ & $1,550,000$ & $1,600,000$ & $1,650,000$ & $1,700,000$ \\
\hline $\begin{array}{l}\text { Website Game } \\
\text { Center } 2.0\end{array}$ & $3,600,000$ & $7,440,000$ & $7,680,000$ & $7,920,000$ & $8,160,000$ \\
\hline $\begin{array}{l}\text { Landing Page } \\
\text { SMS Gateaway } \\
\text { Nexmo }\end{array}$ & $6,000,000$ & $12,360,000$ & $12,720,000$ & $13,080,000$ & $14,400,000$ \\
\hline Total Operation & $11,100,000$ & $21,350,000$ & $22,000,000$ & $22,650,000$ & $24,260,000$ \\
\hline General Affairs & & & & & \\
\hline $\begin{array}{l}\text { Branch } \\
\text { Manager Kit }\end{array}$ & $28,120,000$ & $43,764,000$ & $70,412,000$ & $75,540,000$ & $77,900,000$ \\
\hline Working Tools & $3,000,000$ & $3,060,000$ & $6,240,000$ & $9,540,000$ & $12,960,000$ \\
\hline $\begin{array}{l}\text { Administration } \\
\text { Recapitulation }\end{array}$ & $2,400,000$ & $3,000,000$ & $6,000,000$ & $6,000,000$ & $7,200,000$ \\
\hline $\begin{array}{l}\text { Recaptitutation } \\
\text { \& Evaluation }\end{array}$ & $20,400,000$ & $29,760,000$ & $52,440,000$ & $76,440,000$ & $105,600,000$ \\
\hline $\begin{array}{l}\text { Total General } \\
\text { Affairs } \\
\end{array}$ & $53,920,000$ & $79,584,000$ & $135,092,000$ & $167,520,000$ & $203,660,000$ \\
\hline $\begin{array}{l}\text { Total Operating } \\
\text { Cost }\end{array}$ & $1,259,820,000$ & 3,523,664,000 & $10,158,110,000$ & $11,428,654,000$ & $11,447,724,000$ \\
\hline
\end{tabular}

To compute the taxes for Venture B, it starts with the fact that the company had accumulated Net Operating Losses (NOL) of IDR 1,429,044,666. According to UndangUndang nomor 36 Tahun 2008 Pasal 6 ayat (2), if a corporation has net losses, then the loss is compensated with income for the next five years in a row. After the company generate taxable income, the tax rate of $25 \%$ will be used as as stated at Undang-Undang nomor 36 Tahun 2008 pasal 17 ayat (2a).

TABLE VIII: TAX EXPENSES- NORMAL-CASE (IN IDR)

\begin{tabular}{|c|c|c|c|c|c|c|}
\hline Year & $\begin{array}{c}\text { Profit Before } \\
\text { Tax }\end{array}$ & $\begin{array}{l}\text { Net Loss at the } \\
\text { Start of Year }\end{array}$ & $\begin{array}{c}\text { Compensation } \\
\text { Expired }\end{array}$ & $\begin{array}{l}\text { Net Loss at the } \\
\text { End of Year }\end{array}$ & Taxable Profit & Tax Expenses \\
\hline 2017 & $(1,140,478,935)$ & & & $(1,140,478,935)$ & 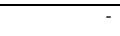 & - \\
\hline 2018 & $(288,565,731)$ & $(1,140,478,935)$ & - & $(1,429,044,666)$ & - & . \\
\hline 2019 & $(805,989,112)$ & $(1,429,044,666)$ & - & $(2,235,033,778)$ & - & . \\
\hline 2020 & $(1,431,601,011)$ & $(2,235,033,778)$ & - & $(3,666,634,789)$ & - & . \\
\hline 2021 & $\begin{array}{l}(2,796,518,050) \\
\end{array}$ & $\begin{array}{l}(3,666,634,789) \\
\end{array}$ & - & $\begin{array}{l}(6,463,152,839) \\
\end{array}$ & - & . \\
\hline 2022 & $377,530,125$ & $(6,463,152,839)$ & & $(6,085,622,714)$ & & \\
\hline 2023 & $9,860,793,026$ & $(6,085,622,714)$ & $762,948,810$ & & $4,538,119,122$ & $1,134,529,780$ \\
\hline
\end{tabular}

\section{e) Additional Reinvestment}

Additional reinvestment each year for the next five years will be the operating cost needed as described before. However, after year 5 , operating cost needed is assumed to be the same with year 5 based on percentage of sales.

\section{f) Pro Forma Financial Statements}

After determining the revenues, COS, operating cost, and taxes, pro forma financial statements can be made. Since Venture B is fully funded by Telkom and does not have any debt or loan, there will be no interest expense computed in the income statement. In addition, the venture does not have any other income or investment that could generate interest income, thus there will be also no interest income computed.

TABLE IX: PRO FORMA INCOME STATEMENT - NORMAL-CASE (IN IDR)

\begin{tabular}{|c|c|c|c|c|c|}
\hline Description & 2019 & 2020 & 2021 & 2022 & 2023 \\
\hline Revenues & $3,244,838,283$ & $18,288,517,124$ & $67,039,443,797$ & $152,349,371,045$ & $219,393,272,115$ \\
\hline Cost of Sales & $2,795,207,395$ & $16,196,454,135$ & $59,677,851,846$ & $140,543,186,920$ & $198,084,755,089$ \\
\hline Gross Profit & $449,630,888$ & $2,092,062,989$ & $7,361,591,950$ & $11,806,184,125$ & $21,308,517,026$ \\
\hline People & $459,000,000$ & $1,584,760,000$ & $4,275,270,000$ & $6,374,160,000$ & $7,429,920,000$ \\
\hline Marketing & $731,600,000$ & $1,837,970,000$ & $5,725,748,000$ & $4,864,324,000$ & $3,789,884,000$ \\
\hline Operation & $11,100,000$ & $21,350,000$ & $22,000,000$ & $22,650,000$ & $24,260,000$ \\
\hline $\begin{array}{l}\text { General } \\
\text { Affairs }\end{array}$ & $53,920,000$ & $79,584,000$ & $135,092,000$ & $167,520,000$ & $203,660,000$ \\
\hline $\begin{array}{l}\text { Total } \\
\text { Operating } \\
\text { Cost }\end{array}$ & $1,255,620,000$ & $3,523,664,000$ & $10,158,110,000$ & $11,428,654,000$ & $11,447,724,000$ \\
\hline $\begin{array}{l}\text { EBITDA } \\
\text { Depreciation }\end{array}$ & $(805,989,112)$ & $(1,431,601,011)$ & $(2,796,518,050)$ & $377,530,125$ & $9,860,793,026$ \\
\hline $\begin{array}{l}\text { \& } \\
\text { Amortization }\end{array}$ & - & - & - & & \\
\hline $\begin{array}{l}\text { Total } \\
\text { Operating } \\
\text { Profit (EBIT) }\end{array}$ & $(805,989,112)$ & $(1,431,601,011)$ & $(2,796,518,050)$ & $377,530,125$ & $9,860,793,026$ \\
\hline $\begin{array}{l}\text { Interest } \\
\text { Income }\end{array}$ & - & - & - & & \\
\hline $\begin{array}{r}\text { Interest } \\
\text { Expenses }\end{array}$ & - & - & - & - & - \\
\hline $\begin{array}{l}\text { Profit Before } \\
\text { Tax }\end{array}$ & $(805,989,112)$ & $(1,431,601,011)$ & $(2,796,518,050)$ & $377,530,125$ & $9,860,793,026$ \\
\hline $\begin{array}{c}\text { Tax } \\
\text { Expenses }\end{array}$ & - & - & - & & $1,134,529,780$ \\
\hline Net Profit & $(805,989,112)$ & $(1,431,601,011)$ & $(2,796,518,050)$ & $377,530,125$ & $8,726,263,245$ \\
\hline
\end{tabular}

Assets that Venture B have is only cash which numbers computed in Balance Sheet come from calculation in Statement of Cash Flow. The venture will not make any investment regarding marketable securities. However, Venture B has Account Payable computed which numbers obtained from the total top up made by merchants. It is assumed that the payable will be $19.22 \%$ of sales each month according to Damodaran's data in Emerging Market for Software (Entertainment) industry.

To compute the equity account, there will be Telkom Fund and Retained Earnings input in the calculation. Both Telkom Fund and Retained Earnings in first period are 
resulted from addition of last year data and forecasted data. Telkom will stop providing the fund in September 2021.

TABLE X: PRO FORMA BALANCE SHEET - NORMAL-CASE (IN IDR)

\begin{tabular}{|c|c|c|c|c|c|}
\hline Description & 2019 & 2020 & 2021 & 2022 & 2023 \\
\hline \multirow{2}{*}{\multicolumn{6}{|c|}{$\begin{array}{l}\text { Assets } \\
\text { Current }\end{array}$}} \\
\hline & & & & & \\
\hline \\
\hline $\begin{array}{r}\text { Account } \\
\text { Receivable }\end{array}$ & - & - & - & - & - \\
\hline Inventory & - & - & - & - & - \\
\hline $\begin{array}{l}\text { Marketabl } \\
\text { e Securities }\end{array}$ & - & - & - & - & . \\
\hline Total & & & & & \\
\hline $\begin{array}{l}\text { Current } \\
\text { Assets }\end{array}$ & $825,118,223$ & $3,245,550,098$ & $9,004,402,620$ & $10,932,307,360$ & $20,180,613,359$ \\
\hline \multirow{2}{*}{\multicolumn{6}{|c|}{$\frac{\text { Non-Current }}{\text { Assets }}$}} \\
\hline & & & & & \\
\hline$\frac{\frac{1000}{\text { Land }}}{\text { L }}$ & - & - & - & - & - \\
\hline Plant \& & . & . & . & . & . \\
\hline Equipment & & & & & \\
\hline Intangible & - & - & - & - & - \\
\hline Total Non- & & & & & \\
\hline $\begin{array}{l}\text { Current } \\
\text { Assets }\end{array}$ & - & - & - & - & \\
\hline Total Assets & $825,118,223$ & $3,245,550,098$ & $9,004,402,620$ & $10,932,307,360$ & $20,180,613,359$ \\
\hline \\
\hline & & & & & \\
\hline & & & & & \\
\hline $\begin{array}{l}\text { Account } \\
\text { Payable }\end{array}$ & $116,837,001$ & $445,205,888$ & $1,601,536,459$ & $3,151,911,074$ & $3,672,903,828$ \\
\hline Accruals & - & - & - & - & - \\
\hline \multirow{2}{*}{\multicolumn{6}{|c|}{ Total }} \\
\hline & & & & & \\
\hline Current & $116,837,001$ & $445,205,888$ & $1,601,536,459$ & $3,151,911,074$ & $3,672,903,828$ \\
\hline Liability & & & & & \\
\hline \multicolumn{6}{|l|}{$\frac{\text { Non-Current }}{\text { Sighilitent }}$} \\
\hline \multicolumn{6}{|l|}{$\frac{\text { Liability }}{\text { Bank }}$} \\
\hline $\begin{array}{l}\text { Bank } \\
\text { Loan }\end{array}$ & - & - & - & - & - \\
\hline Bond & - & - & - & - & \\
\hline Payable & - & - & & & \\
\hline Total Non- & & & & & \\
\hline Current & - & - & - & - & - \\
\hline Total & & & & & \\
\hline Liability & $116,837,001$ & $445,205,888$ & $1,601,536,459$ & 3,151,911,074 & 3,672,903,828 \\
\hline \multicolumn{6}{|l|}{ Equity } \\
\hline $\begin{array}{l}\text { Telkom } \\
\text { Fund }\end{array}$ & $2,947,515,000$ & $6,471,179,000$ & $13,870,219,000$ & $13,870,219,000$ & $13,870,219,000$ \\
\hline $\begin{array}{l}\text { Retained } \\
\text { Earnings }\end{array}$ & $(2,239,233,778)$ & $(3,670,834,789)$ & $(6,467,352,839)$ & $(6,089,822,714)$ & $2,637,490,531$ \\
\hline $\begin{array}{l}\text { Total } \\
\text { Equity }\end{array}$ & $708,281,222$ & $2,800,344,211$ & $7,402,866,161$ & $7,780,396,286$ & $16,507,709,531$ \\
\hline $\begin{array}{l}\text { Total } \\
\text { Liability \& } \\
\text { Equity } \\
\end{array}$ & $825,118,223$ & $3,245,550,098$ & $9,004,402,620$ & $10,932,307,360$ & $20,180,613,359$ \\
\hline $\begin{array}{l}\text { Balance } \\
\text { Check }\end{array}$ & - & - & - & - & \\
\hline
\end{tabular}

Pro Forma Statement of Cash Flow is made based on Pro Forma Income Statement and Pro Forma Balance Sheet. The beginning cash in year 2019 is obtained from historical statement of cash flow in the end of 2018.

TABLE XI: PRo FoRMA STATEMENT OF CASH FLOW - NORMAL-CASE (IN IDR)

\begin{tabular}{|c|c|c|c|c|c|}
\hline Description & 2019 & 2020 & 2021 & 2022 & 2023 \\
\hline Net Income & $(810,189,112)$ & $(1,431,601,011)$ & $(2,796,518,050)$ & $377,530,125$ & $8,727,313,245$ \\
\hline $\begin{array}{l}\text { Depreciation } \\
\text { (Increase)/Decre }\end{array}$ & - & & & - & - \\
\hline ase in Account & - & - & - & - & - \\
\hline $\begin{array}{l}\text { Receivables } \\
\text { (Increase)/Decre } \\
\text { ase in Inventory } \\
\text { Increase/(Decrea }\end{array}$ & - & & & & - \\
\hline $\begin{array}{l}\text { se) in Account } \\
\text { Pavabbles }\end{array}$ & $107,689,501$ & $328,368,887$ & $1,156,330,571$ & $1,550,374,615$ & $520,992,754$ \\
\hline $\begin{array}{l}\text { Increase/(Decrea } \\
\text { se) in Accruals }\end{array}$ & - & - & & & - \\
\hline $\begin{array}{l}\text { Total Cash Flow } \\
\text { from Operating } \\
\text { Activities }\end{array}$ & $(702,499,611)$ & $(1,103,232,125)$ & $(1,640,187,478)$ & $1,927,904,740$ & $9,248,305,999$ \\
\hline $\begin{array}{l}\text { (Increase)/Decre } \\
\text { ase in Marketable } \\
\text { Securities }\end{array}$ & - & - & - & - & - \\
\hline $\begin{array}{l}\text { Securities } \\
\text { (Increase)/Decre } \\
\text { ase in Land } \\
\text { (Increase)/Decre }\end{array}$ & - & - & - & - & - \\
\hline $\begin{array}{l}\text { ase in Plant \& } \\
\text { Equipment }\end{array}$ & - & - & - & - & - \\
\hline $\begin{array}{l}\text { (Increase)/Decre } \\
\text { ase in Intangibles }\end{array}$ & - & - & - & - & $\begin{array}{c}- \\
-\end{array}$ \\
\hline $\begin{array}{l}\text { Total Cash Flow } \\
\text { from Investing } \\
\text { Activities }\end{array}$ & - & - & - & - & - \\
\hline $\begin{array}{r}\text { Increase/(Decrea } \\
\text { se) in Telkom Fund }\end{array}$ & $1,259,820,000$ & $3,523,664,000$ & $7,399,040,000$ & - & - \\
\hline $\begin{array}{l}\text { Total Cash Flow } \\
\text { from Financing } \\
\text { Activities }\end{array}$ & $1,259,820,000$ & $3,523,664,000$ & $7,399,040,000$ & - & - \\
\hline Net Cash Flow & $\begin{array}{l}557,320,389 \\
\end{array}$ & $2,420,431,875$ & $\overline{5,758,852,522}$ & $\begin{array}{l}1,927,904,740 \\
\end{array}$ & $\overline{9,248,305,999}$ \\
\hline Begin & $267,797,834$ & $825,118,223$ & $3,245,550,098$ & $9,004,402,620$ & $10,932,307,360$ \\
\hline Ending Cash & $825,118,223$ & $3,245,550,098$ & $9,004,402,620$ & $10,932,307,360$ & $20,180,613,359$ \\
\hline
\end{tabular}

g) Free Cash Flow

Since Venture B does not have capital expenditures, it can be considered that the operating cash flow is the free cash flow. Cash flow from operating activities indicates the ability of a company to generate the amount of money from its core business activities.

\section{2) Estimating Discount Rate}

The discount rate that will be used in the valuation is Weighted Average Cost of Capital (WACC) of Telkom because the analysis is conducted through Telkom's point of view as the investor, thus Telkom should make an investment that will give return at least as much as its cost of capital. Weight of debt and equity is determined based on capital structure of Telkom in 2018.

\begin{tabular}{lcc}
\multicolumn{4}{c}{ TABLE XII: TELKOM'S CAPITAL STRUCTURE (IN MILLION IDR) } \\
\hline \hline \multicolumn{1}{c}{ Capital Structure } & 2018 & Weight \\
\hline Short-Term & $4,043,000$ & $2.83 \%$ \\
Long-Term & $40,044,000$ & $28.00 \%$ \\
Debt & $44,087,000$ & $30.83 \%$ \\
\hline Equity & $98,910,000$ & $69.17 \%$ \\
\hline Total Capital Invested & $142,997,000$ & $100.00 \%$ \\
\hline \multicolumn{3}{c}{ Source: Telkom Annual Report 2018 }
\end{tabular}

Cost of debt is estimated based on average data of interest rate of short-term debt and long-term debt that Telkom has made. Each of them has different interest rate, as seen in the table below.

TABLE XIII: TELKOM'S COST OF DEBT

\begin{tabular}{|c|c|c|c|}
\hline Long-Term Debt & $\begin{array}{c}\text { Interest } \\
\text { Rate }\end{array}$ & Short-Term Debt & $\begin{array}{c}\text { Interest } \\
\text { Rate } \\
\end{array}$ \\
\hline Two-Step Loans & $7.50 \%$ & Bank Loan & \\
\hline Bonds & $11.00 \%$ & BNI & $9.00 \%$ \\
\hline Notes Payable & $8.35 \%$ & MUFG Bank & $7.30 \%$ \\
\hline Bank Loan & $11.00 \%$ & DBS & $11.00 \%$ \\
\hline Other Loan & $8.35 \%$ & UOB & $8.10 \%$ \\
\hline Average Interest Rate & $9.24 \%$ & HSBC & $14.34 \%$ \\
\hline \multirow[t]{3}{*}{ (a) } & & SCB & $10.50 \%$ \\
\hline & & CIMB Niaga & $11.50 \%$ \\
\hline & & Average Interest Rate & $10.26 \%$ \\
\hline
\end{tabular}

(b)

Source: Telkom Annual Report 2018

The data used to calculate levered beta is obtained from slope of monthly return from historical market price of Telkom and Jakarta Stock Exchange Composite Index. The risk-free rate is using IBPA 10 years Government Bond Yield and the risk premium is using Data Damodaran in Emerging Markets.

\begin{tabular}{lr}
\multicolumn{2}{c}{ TABLE XIV: TELKOM'S COST OF EQUITY } \\
\hline \hline Levered Beta & 0.56 \\
Risk-Free Rate & $7.46 \%$ \\
Risk Premium & $8.59 \%$ \\
\hline Cost of Equity & $12.27 \%$ \\
\hline \hline
\end{tabular}

Then, WACC of Telkom can be estimated.

TABLE XV: TELKOM'S WACC

\begin{tabular}{lrrr}
\hline \hline \multicolumn{1}{c}{ Description } & Weight & \multicolumn{1}{c}{ Cost } & \multicolumn{1}{c}{$\begin{array}{c}\text { Weighted } \\
\text { Cost }\end{array}$} \\
\hline Cost of Short-Term Debt (After Tax) & $2.83 \%$ & $8.21 \%$ & $0.23 \%$ \\
Cost of Long-Term Debt (After Tax) & $28.00 \%$ & $7.39 \%$ & $2.07 \%$ \\
Cost of Equity & $69.17 \%$ & $12.27 \%$ & $8.49 \%$ \\
\hline \multicolumn{2}{c}{ WACC } & & $10.79 \%$ \\
\hline \hline
\end{tabular}

Telkom's cost of capital is $10.79 \%$ and assumed will be constant for the next five years.

\section{3) Estimating Terminal Value}

To estimate the terminal value of Venture $B$, cash flow 
growing in perpetuity will be assumed. It is the most suitable approach because Venture B can be considered successful if it can become Business As Usual of Telkom. The growth rate after year 5 is assumed to be stable at the rate of Indonesia Information and Communication GDP growth in 2018 which is $1.67 \%$. It is the industry where Telkom is operating.

The first thing to do is estimating revenues, COS, and operating cost in year 6 . COS in year 6 is assumed to be $89.96 \%$ from revenues which is average COS from year 2019 to 2023. Operating cost in year 6 is assumed to be $3.90 \%$ from revenues, the same as year 5. After that, Pro Forma Financial Statement for year 6 can be made.

The cost of capital in the stable period will be also Telkom's WACC since Venture B is assumed to become Business As Usual of Telkom after year 5. After determining all the input needed, terminal value can be estimated, and the result is IDR 100,333,524,141.

\section{4) Present Value of Venture $B$}

After estimating all the data needed to compute valuation, finally the value of Venture $\mathrm{B}$ can be determined.

TABLE XVI: EXPECTED CASH FLOW AND VALUE - NORMAL-CASE (IN IDR)

\begin{tabular}{|c|c|c|c|c|c|}
\hline Description & 2019 & 2020 & 2021 & 2022 & 2023 \\
\hline $\begin{array}{c}\text { Free } \\
\text { Cash Flow }\end{array}$ & $(702,499,611)$ & $(1,103,232,125)$ & $(1,640,187,478)$ & $1,927,904,740$ & $9,248,305,999$ \\
\hline $\begin{array}{c}\text { Terminal } \\
\text { Value }\end{array}$ & - & & - & & $100,333,524,141$ \\
\hline $\begin{array}{l}\text { Total Cash } \\
\text { Flow }\end{array}$ & $(702,499,611)$ & $(1,103,232,125)$ & $(1,640,187,478)$ & $1,927,904,740$ & $109,581,830,140$ \\
\hline $\begin{array}{l}\text { PV of Total } \\
\text { Cash Flow }\end{array}$ & $(702,499,611)$ & $(995,783,139)$ & $(1,336,254,652)$ & $1,417,683,152$ & $72,732,752,862$ \\
\hline $\begin{array}{l}\text { Enterprise } \\
\text { Value }\end{array}$ & $71,115,898,612$ & & & & \\
\hline
\end{tabular}

The result of enterprise value needs to be adjusted for survival. The chosen way will be simulations and the method used to conduct the simulations is First Chicago method.

\section{5) First Chicago Method}

The previous valuation calculated is for the normal-case scenario, whereas the worst-case and best-case scenario calculation will be presented hereafter.

\section{a) Worst-case Scenario}

In worst-case scenario, it is assumed that PC Game Voucher will be sold $80 \%$ of sales in normal-case. COS of PC Game Voucher will be estimated using the same percentage of sales in normal-case. For Mobile Game Voucher, it is assumed that Venture B could only reach $0.003 \%$ market share in year 1 and grow until $0.08 \%$ in year 5. COS of Mobile Game Voucher will be estimated using the same percentage of sales in normal-case. For Bundling Voucher, it is assumed that Venture B is still possible to acquire merchants the same amount as in the normal scenario. However, the users of every merchant are assumed to be fewer than normal scenario which are two people per two hours in weekdays and five people per two hours in weekends, thus total users per month will be 490 . The price and COS of Bundling Voucher will be the same as the normal-case.

Operating cost and tax rate in the worst-case are assumed to be the same with the normal-case. After estimated the condition in the worst-case, Pro Forma Financial Statement can be determined.

Required return and the stable growth rate are assumed to be the same with normal scenario. The same step as in the normal-case calculation, terminal value needs to be estimated in the worst-case the result is IDR $45,429,181,509$. Then, the value of Venture B in the worstcase can be seen in the table below.

\begin{tabular}{lcccccc}
\multicolumn{6}{c}{ TABLE XVII: EXPECTED CASH FLOW AND VALUE - WORST-CASE (IN IDR) } \\
\hline \hline Description & 2019 & 2020 & 2021 & 2022 & 2023 \\
\hline $\begin{array}{c}\text { Free } \\
\text { Cash Flow } \\
\text { Termi } \\
\text { nal Value } \\
\text { Total } \\
\text { Cash Flow }\end{array}$ & $(903,444,669)$ & $(1,875,245,294)$ & $(4,490,914,541)$ & $(2,542,050,130)$ & $3,006,808,506$ \\
\hline $\begin{array}{l}\text { PV of } \\
\text { Total Cash } \\
\text { Flow }\end{array}$ & - & - & - & - & $45,429,181,509$ \\
\hline \hline $\begin{array}{l}\text { Enterprise } \\
\text { Value }\end{array}$ & $(903,444,669)$ & $(1,875,245,294)$ & $(4,490,914,541)$ & $(2,542,050,130)$ & $48,435,990,014$ \\
\hline
\end{tabular}

\section{b) Best-case Scenario}

In best-case scenario, it is assumed that PC Game Voucher will be sold $120 \%$ of sales in normal-case. COS of PC Game Voucher will be estimated using the same percentage of sales in normal-case. For Mobile Game Voucher, it is assumed that Venture B could capture $0.007 \%$ market share in year 1 and reach $0.12 \%$ in year 5 . COS of Mobile Game Voucher will be estimated using the same percentage of sales in normal-case. For Bundling Voucher, it is assumed that Venture B can acquire 200 merchants in year 1 and 7500 merchants in year 5 with the total users in every merchant are expected to be the same with normalcase scenario. The price and COS of Bundling Voucher will be the same as the normal-case.

TABLE XVIII: PROJECTED MERCHANTS ACQUISITION - BEST-CASE (IN

\begin{tabular}{lcccccc}
\multicolumn{7}{c}{ IDR) } \\
\hline \hline \multirow{1}{*}{ Island } & 2019 & 2020 & 2021 & 2022 & 2023 & \\
& Merchants & Merchants & Merchants & Merchants & Merchants & Total \\
& Acquired & Acquired & Acquired & Acquired & Acquired & \\
\hline Jawa & 200 & 790 & 1,940 & 2,025 & 485 & 5,440 \\
Bali \& Nusa & - & 37 & 56 & 72 & 38 & 203 \\
Sumatra & - & 148 & 327 & 370 & 152 & 997 \\
Kalimantan & - & - & 107 & 153 & 68 & 328 \\
Sulawesi & - & - & 116 & 181 & 80 & 377 \\
Maluku-Papua & - & - & 49 & 59 & 47 & 155 \\
\hline Total & 200 & 975 & 2,595 & 2,860 & 870 & 7,500 \\
\hline Accumulative & 200 & 1,175 & 3,770 & 6,630 & 7,500 & \\
\hline \hline
\end{tabular}

Operating cost and tax rate in the best-case are assumed to be the same with the normal-case. After estimated the condition in the best-case, Pro Forma Financial Statement, can be determined.

Required return and stable growth rate are assumed to be the same with normal-case scenario. The same step as in the normal-case calculation, terminal value needs to be estimated in the best-case and the result is IDR $204,832,922,982$. Then, the value of Venture B in the bestcase can be seen in the table below.

TABLE XIX: EXPECTED CASH FLOW AND VALUE - BEST-CASE (IN IDR)

\begin{tabular}{|c|c|c|c|c|c|}
\hline Description & 2019 & 2020 & 2021 & 2022 & 2023 \\
\hline $\begin{array}{c}\text { Free } \\
\text { Cash Flow }\end{array}$ & $(574,859,772)$ & $(193,046,189)$ & $2,407,226,545$ & $7,395,802,228$ & $16,944,608,122$ \\
\hline $\begin{array}{l}\text { Terminal } \\
\text { Value }\end{array}$ & - & - & - & - & $204,832,922,982$ \\
\hline $\begin{array}{l}\text { Total Cash } \\
\text { Flow }\end{array}$ & $(574,859,772)$ & $(193,046,189)$ & $2,407,226,545$ & $7,395,802,228$ & $221,777,531,103$ \\
\hline $\begin{array}{l}\text { PV of Total } \\
\text { Cash Flow } \\
\end{array}$ & $(574,859,772)$ & $(174,244,509)$ & $1,961,158,533$ & $5,438,497,036$ & $147,200,410,318$ \\
\hline $\begin{array}{l}\begin{array}{l}\text { Enterprise } \\
\text { Value }\end{array} \\
\end{array}$ & $153,850,961,606$ & & & & \\
\hline
\end{tabular}

\section{c) Valuation Result}

From the calculation conducted, the value in every scenario can be summarized as follows. 
TABLE XX: VENTURE B'S VALUE IN EVERY SCENARIO (IN IDR)

\begin{tabular}{lr}
\hline \multicolumn{1}{c}{ Scenario } & \multicolumn{1}{c}{ Enterprise Value } \\
\hline Worst Case & $24,024,344,912$ \\
Normal Case & $71,115,898,612$ \\
Best Case & $153,850,961,606$ \\
\hline
\end{tabular}

To find the final value of Venture B, probabilities of each scenario needs to be estimated. The probability of best-case scenario will be 0.1 since it is possible to happen, but it needs extra hard work from every employee whereas as stated in SWOT analysis, one of Venture B's weaknesses is less engage outsource employees thus may make them not work as hard as the C-level employees do. The probability of normal-case scenario and worst-case scenario both will be 0.45 because both of them are likely to happen.

$$
\begin{aligned}
\text { Enterprise Value } & =\text { weight worst case }+ \text { weight normal case } \\
& + \text { weight best case } \\
& =0.45(\text { IDR } 24,024,344,912) \\
& +0.45(I D R 71,115,898,612) \\
& +0.1(I D R 153,850,961,606) \\
& =I D R 58,198,205,746
\end{aligned}
$$

\section{Valuation of Venture B (Second Condition - Existing)}

As the additional investment does not happen in this condition, the revenue stream will only come from PC Voucher Game. All the assumptions made in the valuation of existing condition are same as in the normal-case scenario if Telkom give the additional investment. However, the tax rate that will be included in the calculation will be deducted $50 \%$ as stated in Undang-Undang nomor 36 Tahun 2008 Pasal 31E ayat (1) that local corporation with gross income up to IDR 50 billion will get tax reduction $50 \%$ from normal tax rate that is levied on Taxable Income from the gross income portion of up to IDR 4,800,000,000.

Using the same calculation in the previous section,

\begin{tabular}{|c|c|c|c|c|c|}
\hline & 2019 & 2020 & 2021 & 2022 & 2023 \\
\hline $\begin{array}{l}\text { Free Cash Flow } \\
\text { Terminal Value }\end{array}$ & $11,803,190$ & $15,277,461$ & $14,111,060$ & $13,226,352$ & $\begin{array}{r}12,521,160 \\
126,853,599\end{array}$ \\
\hline Total Cash Flow & $11,803,190$ & $15,277,461$ & $14,111,060$ & $13,226,352$ & $139,374,759$ \\
\hline $\begin{array}{l}\text { PV of Total Cash } \\
\text { Flow }\end{array}$ & $11,803,190$ & $13,789,517$ & $11,496,228$ & $9,725,987$ & $92,507,215$ \\
\hline Enterprise Value & $139,322,137$ & & & & \\
\hline
\end{tabular}
discount rate of Telkom's WACC, and perpetuity growth of $1.67 \%$, the terminal value is estimated to be IDR $126,853,599$ and the value of the venture is as follows.

TABLE XXI: EXPECTED CASH FLOW AND VALUE - EXISTING CONDITION (IN IDR)

\section{Analysis of Valuation}

To determine whether funding should be provided by Telkom, the valuation under two different conditions should be compared and analyzed.

TABLE XXII: VALUATION OF VENTURE B IN DifFERENT CONDITIONS (IN IDR)

\begin{tabular}{lr}
\hline \hline \multicolumn{1}{c}{ Condition } & \multicolumn{1}{c}{ Enterprise Value } \\
\hline Worst Case & $24,024,344,912$ \\
Normal Case & $71,115,898,612$ \\
Best Case & $153,850,961,606$ \\
\hline FCM & $58,198,205,746$ \\
Existing & $139,322,137$ \\
\hline \hline
\end{tabular}

Based on Table XXII, it is found that if Telkom gives additional investment, the value of the venture will be much bigger than existing condition even if it faces the worst-case because it will give Venture B opportunity to get new revenue stream from mobile game segment which growth is predicted to become huge in the future.

\section{CONCLUSION AND RECOMMENDATION}

\section{A. Conclusion}

Based on the results of analysis and valuation, it can be concluded that the venture has opportunity to grow big and will be valuable for Telkom. Venture B could help leveraging assets and capabilities of Telkom to help create new business. Currently, Telkom has not had a product or business unit that has business model as Venture B, thus it can help Telkom to reach new market and create new revenue stream. However, if Telkom does not give additional fund, the venture will not be able to develop new revenue stream.

Based on calculation in condition which Telkom will give additional fund, Telkom will give the fund until September 2021 in each scenario. Therefore, total amount of Telkom's equity will be IDR $13,870,219,000$. Value of the venture resulted if it is given additional fund is bigger than Telkom's total equity, even in the worst condition. However, if Telkom will not give the additional fund, total amount of Telkom's equity is IDR 1,687,695,000 and the venture's value is lower than the equity which is IDR $139,322,137$.

\section{B. Recommendation}

Based on the conclusion, there are some recommendation can be considered that Telkom should give the additional fund to Venture B since the calculation resulted in higher enterprise value than total fund that Telkom gives to the venture, even in worst condition. However, Telkom has to be patient because it takes years for a venture to reach profitability. Corporate venturing is a long-term project for at least five years. Telkom should consider giving fund if the venture can show the potential revenue for the product or service provided and the characteristics of the industry which the venture operates has potential to grow.

To make the corporate venturing implementation successful, both parent company and venture should give benefit to each other. Venture B has to help the Telkom improve Telkom's competitive position and financial performance. Telkom also has to not only provide the fund to the venture but give financial and nonfinancial rewards. Telkom should support them to fully unleash their potential by facilitating the creative working environment and compensating the corporate entrepreneurs. Hence, Telkom will get not only financial return, but also employees' retention because the employees will feel of selfachievement and more job satisfaction.

Although Venture B starts the new business with clearly defined goals and objectives through its business model, it needs to be flexible to fit reality. The venture should make adjustment if there are changes in industry environment and market to maintain and develop profitability and growth. Therefore, evaluation must be done periodically.

\section{REFERENCES}

(Periodical style)

[1] Admin. (2018, May 12). How Gaming Technology Has Improved. Retrieved from https://www.gamedesigning.org/gaming/advances-intechnology/ 
[2] Costanza, T. (2012, July 10). The Environmental Impact of Video Games (Infographic). Retrieved from https://www.siliconrepublic.com/life/the-environmental-impact-ofvideo-games-infographic

[3] Damodaran, A. (2000, March). The Dark Side of Valuation: Firms with no Earnings, no History and no Comparables. New York City, New York, USA.

[4] Damodaran, A. (2012). Investment Valuation (3rd Ed.): Tools and Techniques for Determining the Value of Any Asset. New Jersey: John Wiley \& Sons, Inc.

[5] Decision Lab. (2018). A Behavioral Analysis of Mobile Games. Ho Chi Minh City: Decision Lab.

[6] Fischer, J. (2014, August 5). Five-Forces Analysis has Grim Tidings for Free-To-Play on Mobile. Retrieved from https://www.gamasutra.com/blogs/JustinFischer/20140508/217326/Fi veForces_Analysis_has_Grim_Tidings_for_FreeToPlay_on_Mobile.p hp

[7] Futurebooks. (2011). Mobile Game Industry Analysis. Singapore.

[8] Gitman, L. J., \& Zutter, C. J. (2015). Principles of Managerial Finance (Global Edition, 14th Ed.). Harlow, Essex, England: Pearson Education Limited.

[9] Grant, R., Bulter, B., Orr, S., \& Murray, P. (2014). Contemporary Strategic Management. Milton, Australia: Wiley.

[10] Gurel, E., \& Tat, M. (2017). SWOT Analysis: A Theoretical Review. The Journal of International Social Research, 994-1006.

[11] Hisrich, R. D., \& Kearney, C. (2012). Corporate Entrepreneurship: How to Create a Thriving Entrepreneurial Spirit Throughout Your Company. New York City: McGraw-Hill.

[12] Hitt, M. A., Ireland, R. D., \& Hoskisson, R. E. (2011). Concepts Strategic Management: Competitiveness \& Globalization. Mason: South-Western Cengage Learning.

[13] Jha, B. (2017, February 21). How Does New Technology Impact The Gaming Industry? Retrieved from https://www.gamasutra.com/blogs/BinayJha/20170221/291980/How Does_New_Technology_Impact_The_Gaming_Industry.php

[14] Lofgren, K. (2016, November 15). Environmental Impact of Video Games. Retrieved from Bigfishgames: https://www.bigfishgames.com/blog/the-environmental-impact-ofgaming/

[15] Mahesa, R. (2017, April 26). 4 Gaming Innovations that are Impacting All of Tech. Retrieved from https://hub.packtpub.com/4gaming-innovations-are-impacting-all-tech/

[16] Marr, B. (2018). What is Industry 4.0? Here's A Super Easy Explanation For Anyone. Retrieved from Forbes: https://www.forbes.com/sites/bernardmarr/2018/09/02/what-isindustry-4-0-heres-a-super-easy-explanation-foranyone/\#c1a61a69788a

[17] McGuire, A. (2018, May 11). How Technology Continues to Drive The Video Gaming Industry. Retrieved from https://irishtechnews.ie/how-technology-continues-to-drive-the-videogaming-industry-2/

[18] Mountfield, S. (n.d.). Industry Analysis of the Mobile Gaming Industry in Denmark. Retrieved from http://www.mountfield.dk/industryanalysis.pdf

[19] Nabila, M. (2017, April 28). Telkom Resmi Komersialkan Layanan WiFi Corner. Retrieved from Dailysocial: https://dailysocial.id/post/telkom-resmi-komersialkan-layanan-wificorner

[20] Newzoo. (2015). Preview of the Southeast Asian Games Market: Opportunities in the World's Fastest Growing Region. Newzoo.

[21] Newzoo. (2015). Southeast Asia Games Market: The World's Fastest Growing Region Casual Games Sector Report 2015. Newzoo.

[22] Newzoo. (2017). 2017 Global Games Market Report. Newzoo.

[23] Newzoo. (2018). 2018 Global Games Market Report. Newzoo.

[24] Rastogi, N., \& Trivedi, D. M. (2016). Pestle Technique - A Tool to Identify External Risks in Construction Projects. International Research Journal of Engineering and Technology, 384-388.

[25] Reinfeld, P. (2018). Start-Up Valuation: Solving the Valuation Puzzle of New Business Ventures. Paris: HEC Paris.

[26] Rexusid. (2018, February 2). Bisnis Warnet Making Menguntungkan Bersama Rexus. Retrieved from Rexus: https://rexus.id/bisnis-warnetmakin-menguntungkan-bersama-rexus/

[27] Shamil, M., \& Fuad, H. (2019, January 13). Koran Sindo: News. Retrieved from www.koran-sindo.com: http://koransindo.com/page/news/2019-01-13/0/0/Rebut_Pasar_Game_Indonesia

[28] Shantika, E. (2017, April 26). Games, Sisa Kejayaan Laskä penghuni Warnet. Retrieved from CNN Indonesia: https://www.cnnindonesia.com/teknologi/20170422025840-185209405/gamer-sisa-kejayaan-laskar-penghuni-warnet

[29] Statista. (2019). Mobile Games Indonesia. Retrieved from Statista: https:/www.statista.com/outlook/211/120/mobile-games/indonesia

[30] Sudoyo, W. (2018). Valuasi Operator Disamai Unicorn, Telkom Terancam? Retrieved from Telset: https://telset.id/204981/valuasioperator-disamai-unicorn-telkom-terancam/

[31] Takahashi, D. (2016, January 25). Game-software revenues to grow from $\$ 90 B$ in 2016 to $\$ 11 B$ by 2020. Retrieved from Venturebeat: https://venturebeat.com/2016/01/25/game-software-revenuesexpected-to-grow-from-90b-in-2016-to-115b-by-2020/

[32] Telkom Indonesia. (2018). Annual Report 2018. Retrieved from Telkom:

https://www.telkom.co.id/servlet/tk/mobile/about/en US/stockdetail/a nnual-reports.html

[33] Telkom Indonesia. (n.d.). Profile and Brief History. Retrieved from Telkom:

https://www.telkom.co.id/servlet/tk/about/en_US/stocklanding/profile -and-brief-history.html

[34] Tung, Y. H. (2018, August 30). How Singapore Start-up Bountie Aims to Change The E-Sport Scene Using Cryptocurrency. Retrieved from https://e27.co/singapore-start-up-bountie-aims-change-e-sportscene-using-cryptocurrency-20180829/

[35] Utomo, R. M. (2016, April 28). Tumbangnya Warnet Browsing dan Bangkitnya Warnet Gaming. Retrieved from Medcom: https://www.medcom.id/teknologi/news-teknologi/4KZXx0qbtumbangnya-warnet-browsing-dan-bangkitnya-warnet-gaming

[36] Westway, L. (2015, June 5). Dirty Cloud: Warnings Over Online Gaming Industry's Environmental Footprint. Retrieved from https://www.theguardian.com/sustainable-

business/2015/jun/05/warnings-over-online-gaming-industrys-dirtycloud

[37] Wibowo, A. (2016, March 15). Pasar Game Global Diperkirakan Akan Mencapai Lebih dari Rp1.000 Triliun Tahun 2019. Retrieved from Techinasia: https://id.techinasia.com/pasar-game-global-akantembus-rp1-000-triliun-2019-nanti (Telkom Indonesia)

[38] Wisker, G. (2007). The Postgraduate Research Handbook (2nd Edition). London: Red Globe Press.

[39] Zhuo, K. (2017, December 12). Porter's Five Forces Analysis - Video Game. Retrieved from https://medium.com/@keyue.zhuo.14/porters-five-forces-analysisvideo-game-2478241 ebe41

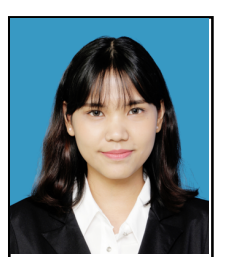

Cynthia Ghaida Subroto was born in Bandung, $28^{\text {th }}$ December 1992. She earned her undergraduate degree (Majoring in Architecture) from Bandung Institute of Technology, Indonesia in 2015. Currently, she is pursuing her master's degree in Master of Business Administration, Bandung Institute of Technology majoring in finance.

From 2015 until 2017, she worked as a fit-out and design architect at Paris Van Java, a famous lifestyle place in Bandung. She had three-months internship at PT Kingsmen Indonesia in 2015 as designer and project executive assistant, and also at PT Telekomunikasi Indonesia in 2019 as staff in internal start-up incubator.

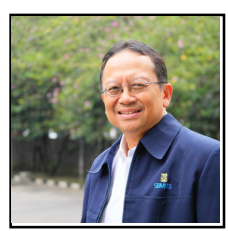

Subiakto Sukarno earned his undergraduate degree (Majoring in Mechanical Engineering) from Bandung Institute of Technology, Indonesia in 1983. He continued his study at Oklahoma State University, USA in 1992 to get MBA degree and get his doctorate degree in Business Administration from Padjadjaran University, Bandung, Indonesia.

He has over 24 years of professional experience in various companies and has been assigned to various management positions such as program manager, finance director, president commissioner, and chairman of audit committee.

Dr. Sukarno received a national level award "Satya Lencana Karya Pembangunan" from President of Indonesia due to his contribution in turbine overhaul technology transfer in country. He has passed Chartered Financial Analyst level I, Registered Financial Associates, Qualified Wealth Planner, and Certified Financial Planner. 